\title{
Zwierzęcy bohaterowie w powieści Crobinhoodovi Dunji Kalilić. Na tropie stereotypów
}

\begin{abstract}
Magdalena, Zwierzęcy bohaterowie w powieści Crobinhoodovi Dunji Kalilić. Na tropie stereotypów (Animal Characters in the Novel Crobinhoodovi by Dunja Kalilić. On the Trail of Stereotypes). "Poznańskie Studia Slawistyczne" 20. Poznań 2021. Publishing House of the Poznań Society for the Advancement of the Arts and Sciences, Adam Mickiewicz University, pp. 175-193. ISSN 2084-3011.

This article analyses how animal characters were presented in the novel Crobinhoodovi by Dunja Kalilić, which belongs to the trend called ratni dječji roman in Croatian literature and shows the Serbian aggression against Croatia. The attention was paid in particular to the issue of stereotypes. The work consists of six parts. The first one is dedicated to the development of Croatian children's animal studies. The second part shows the ways of portraying the war in Croatian literature for the youngest. The third part focuses on stereotypes about animals, the fourth one describes the stereotypical images of animals and people presented in the writer's work, and the fifth part deals with national stereotypes. The last part is a summary of the considerations and presents the conclusion that the novel Crobinhoodovi makes it a goal to properly shape the child's worldview, which is achieved by building and consolidating the negative stereotype of the Serbian soldiers.
\end{abstract}

KeYwords: Crobinhoodovi; Dunja Kalilić; Croatian war novel for children; animals; stereotypes

\section{Chorwacka animalistyka dziecięca}

Zwierzęta są nieodzownym elementem kultury i popkultury adresowanej do dzieci. Przenikają na wskroś ich codzienność, począwszy od ubrań i zabawek, aż po piosenki, filmy i książki. Ich obecność w tekstach dla dzieci jest wieloaspektowa. Kształtują fabułę i służą wyeksponowaniu określonych wartości. Bawią, śmieszą, i - będąc alegoriami - pouczają oraz pomagają wzbudzić empatię. Jako wzorce osobowe oddziałują na małych czytelników, którzy porównują siebie i swoje zachowanie 
z postawami i czynami postaci przedstawionych na kartach utworów. Badacze podkreślają, że o typie bohatera $\mathrm{w}$ tekstach dla najmłodszych decydują przede wszystkim czynniki wychowawcze, to ze względu na nie „bohaterami utworów dla dzieci, [...] w pierwszym rzędzie są zwierzęta” (Cieślikowski, 1975, 271).

Postaci animalistyczne bardzo szybko wkroczyły też do chorwackiej literatury dziecięcej. Dostrzec je można już w najstarszych utworach tego typu - we wczesnych powieściach dla dzieci (rani hrvatski dječji roman ${ }^{1}$ ) autorstwa między innymi Vladimira Nazora ( ̌́arko, 1928), Anticy Juras-Ljubić (Zgode i nezgode Ciplića Njuškalića, 1935), Josipa Selaka (Gojko: po svem svijetu proslavljen majmun-čovjek, 1936) czy Mate Lovraka (Micek, Mucek, Dedek, 1939), a także w zbiorach opowiadań Jure Turicia (Priče, 1907), Ivany Brlić Mažuranić (Priče iz davnine, 1916) i Miroslava Hirtza (Novele iz životinskog svijeta: knjiga jednog prirodnjaka, 1927) oraz na gruncie poezji, gdzie - jak konstatuje Ivo Zalar $(1991,119)$ - „neprestano susrećemo animalističke motive”. Również chorwackie czasopisma dziecięce od samych swych początków były przepełnione ilustracjami zwierząt (Batinić, 2013, 293). Co więcej, jak wynika z analizy przeprowadzonej przez Štefkę Batinić i Berislava Majhuta, co szósta książka obrazkowa dla dzieci (slikovnica) wydana w Chorwacji do roku 1945 podejmowała tematykę animalistyczną (v. Batinić, Majhut, 2001, 67).

Zwierzęta obecne są również w tekstach nowszych, zwłaszcza powstających od lat 70. XX wieku, kiedy to - jak zaznacza Kristina Slunjski (2020, 121) - „zanimanje za animalistiku jača”. Wizerunki zwierząt pojawiają się między innymi w utworach Sunčany Škrinjarić, Ivanki Glogović Klarić, Anđelki Matić, Božidara Prosenjaka, Višnji Strahuljak, Vlatka Šaricia, Nikoli Pulicia, Hrvoja Hitreca, Nady Iveljić oraz Mai Gluščević², która określana

${ }^{1}$ Termin wprowadzony do badań nad chorwacką powieścią dziecięcą przez Berislava Majhuta, określający utwory wydane do roku 1945. Badacz jako cezurę zamykającą okres rani hrvatski dječji roman wskazuje ten rok, gdyż wówczas - jak sam pisze: „došlo je do radikalnog loma tradicije” (Majhut, 2005, 44), przestały działać szczycące się wieloletnim uznaniem instytucje, takie jak: Knjižnica za mladež, Smilje oraz oficyna wydawnicza Kugli.

${ }^{2}$ Autorka ma w dorobku trzynaście książek, których bohaterami są zwierzęta: Jelenko, 1982; Vuk samotnjak, 1983; Bundaš iz petog be, 1987; Bijeg u košari, 1992; Ivin vučko, 1995; Klopka za medvjedića, 1994; Neman u gradskom parku, 1995; Priča o tatinoj vjeverici, 1998; Tko je oteo Dolores, 1998; Džeki zvan Simpa, 2003; Tajna Tihe uvale, 2004; Piki i Argo, 2006; Tišina, snima se! (avanture jednog psa sa snimanja filma Vuk samotnjak), 2009. Utwory 
jest mianem ,ponajbolja domaća spisateljica animalističke proze” (Kujundžić, 2015, 28; cf. Hranjec 1998, 241; cf. Pilaš, 1998, 34). Tak duże zainteresowanie tematyką zwierzęcą sprawiło, że na gruncie chorwackim:

Sve su vrste dječje književnosti prepune životinja. Ima ih u narodnim pričama i dječjoj usmenoj poeziji, u njihove su likove obučeni ljudski tipovi u basnama, u umjetničkoj priči i u romanu o djetinjstvu imaju i pratilačke i glavne uloge, a mogu se sresti u avanturističkom romanu i znanstvenoj fantastici, dok u slikovnici gotovo gospodare (Crnković, Težak, 2002, 170).

Przyczyn takiego stanu rzeczy należy upatrywać przede wszystkim w fakcie, że dzieci niezwykle często postrzegają zwierzęta jako najlepszych przyjaciół a - jak zauważa Ana Batinić - „na kućne ljubimce reagiraju kao na zanimljive vršnjake" (Batinić, 2013, 293). Z kolei Nikola Visković, pisząc o więzach łączących młodych ludzi ze swoimi pupilami, wskazuje na ich pokrewieństwo, o którym, zdaniem badacza, świadczy między innymi fakt, że z perspektywy ewolucji zwierzęta są „,wiecznymi dziećmi”, co należy tłumaczyć jako „najdublji izvor uzajemne privlačnosti i razumijevanja" (Visković, 2009, 302). Natomiast Dubravka Zima i Marijana Hameršak zwracają uwagę, że więzi łączące dzieci ze zwierzętami mają nie tyle wymiar biologiczny, co przede wszystkim kulturowy (Hameršak, Zima, 2015, 332). Powołując się na spostrzeżenia Simona Flynna, ujmującego naturalną i wzajemną skłonność dzieci i zwierząt oraz łączącą ich bliskość jako konstrukcje kulturowe, badaczki stwierdzają, że: „zasićenost dječje književnosti životinjama također oblikuje predodžbu o nerazdruživosti djece i životinja, pri čemu se ta zasićenost zamjenom teza ponekad tumači kao posljedica navodne srodnosti djece i životinja" (Hameršak, Zima, 2015, 333). Ich zdaniem przywiązanie dzieci do zwierząt należy odczytywać jako jedno z „uogólnień na temat dzieci i dzieciństwa" (generalizacija o djeci i djetinjstvu) ${ }^{3}$ (Hameršak, Zima, 2015, 334).

te cieszą się niesłabnącą popularnością, czemu przysłużyły się również adaptacje filmowe. Gluščević jest autorką scenariuszy do filmu Vuk samotnjak (1972) oraz serialu telewizyjnego Jelenko (1980), które następnie przekształciła w powieści opublikowane pod tymi samymi tytułami. W 1995 roku ekranizacji doczekała się książka Bijeg u košari. Film w reżyserii Tomislava Radicia nosi tytuł Anđele moj dragi.

${ }^{3}$ Badaczki podkreślają, że uogólnienie to sprawia między innymi, iż utwory literackie o tematyce animalistycznej, bez względu na fakt, kto jest ich adresatem, są przez księgarzy 
Konsekwencją przekonania o głębokiej i wręcz nierozerwalnej relacji zwierząt i dzieci oraz o ich rzekomym pokrewieństwie jest również sposób ukazywania tego związku w powieściach dla najmłodszych. Szczególnie widoczne jest to w utworach, których dziecięcy bohaterowie przedstawieni zostają w trudnych sytuacjach życiowych, często granicznych. Dzieciom uwikłanym w problemy, z którymi niejednokrotnie nie potrafiłyby się zmierzyć osoby dorosłe, z odsieczą przychodzą zwierzęta. Są dla nich wsparciem i pomagają wyjść z opresji. Tego typu sytuacje stanowią także oś fabularną utworów, które w chorwackiej literaturze przedmiotu nazywane są powieściami wojennymi dla dzieci (ratni dječji roman).

\section{Powieść wojenna dla dzieci}

Intensywny rozwój tej odmiany gatunkowej w dziejach chorwackiej beletrystyki dziecięcej miał miejsce po II wojnie światowej, a jej renesans nastąpił w latach 90. XX wieku, w okresie chorwacko-serbskiego konfliktu zbrojnego, który w Chorwacji przyjęło się określać mianem Domovinski rat. Autorzy tworzący z myślą o najmłodszych czytelnikach bardzo szybko zareagowali na wojenną zawieruchę, która nagle ogarnęła Chorwację. Już w roku 1991 zagrzebska oficyna Mladost zainicjowała publikację serii Ratna vjeverica, która była „wojenną wersją” cieszącej się niezwykłą popularnością wśród dzieci i młodzieży serii Vjeverica. Pierwszą książką, która ukazała się w jej ramach, był zbiór przygotowany przez Mladena Kušca pt. Ubili su mi kuću. Do końca 1992 roku ukazały się jeszcze trzy utwory o tematyce wojennej-Moj tata spava s anđelima Stjepana Tomaša, Bijeg u košari Mai Gluščević oraz Strah me, mama Nikoli Pulicia. W kolejnych latach po tematykę tę sięgnęli również Nada Iveljić, Hrvoje Hitrec, Vladimir Tadej, Milan Taritaš, Ivan Kušan, Predrag Raos, Dunja Kalilić i Zlatko Krilić. Począwszy od roku 1991 do chwili obecnej ukazało się około trzydziestu książek adresowanych do dzieci i młodzieży, ukazujących zmagania ich rówieśników z koszmarem wojny. Twórcy, chcąc przybliżyć dzieciom tak trudny temat, posłużyli się elementami typowymi dla

i bibliotekarzy automatycznie umieszczane w dziale z literaturą dziecięcą i młodzieżową (v. Hameršak, Zima, 2015, 315). 
współczesnej literatury dla niedorosłych, do których należą między innymi: kategoria bohatera rówieśniczego, przygodowość ${ }^{4}$, przekraczanie tabu, dydaktyzm, paidialność (odniesienia do świata dziecka, jego wyobraźni, myślenia i języka), w ograniczonym zakresie również fantastyka, która uwidacznia się jedynie w wybranych utworach, np. Koko u Kninu czy $\check{C} u$ varice novih krovova, oraz ilustracja ${ }^{5}$. Wspólną cechą niemalże wszystkich omawianych tu utworów jest również konkret historyczny i geograficzny. Akcja nie toczy się „gdzieś w Chorwacji” czy na świecie, ale w Zagrzebiu, Osijeku, Sitnicy, Dubrowniku, Kninie, w slawońskich wioskach czy nadmorskich miasteczkach, do których kierowano uchodźców. Miejscowości porażone wojną, ich ulice, domy, place, kościoły i pomniki uczestniczą $\mathrm{w}$ wydarzeniach i cierpią na równi z bohaterami. Obecny w nurcie ratno pismo topos „miasta nieujarzmionego" dochodzi do głosu także w tekstach adresowanych do najmłodszych. Innymi stałymi tematami pojawiającymi się w niemalże wszystkich utworach są: utrata rodzinnego domu, a wraz z nim również najbliższych, sieroctwo, pełne lub częściowe, wygnanie, powrót w rodzinne strony oraz odbudowa domu. Wydarzenia pozornie ukazane zostały z perspektywy dziecka. „Takie przynajmniej wrażenie mają sprawić prezentowane teksty" (Dyras, 1999, 187). Sprzyja temu zasada rówieśnictwa opierająca się na „wiekowej odpowiedniości literackiej postaci i potencjalnego czytelnika, [która] zapewnia zniesienie pokoleniowego dystansu, proponuje określone analogie poznawcze i emocjonalne" - co akcentuje Katarzyna Wądolny-Tatar $(2017,114)$. Warto jednak podkreślić, że kategoria bohatera rówieśniczego nie pozostaje bez znaczenia dla walorów dydaktycznych oraz wychowawczych literatury dla najmłodszych, co w przypadku nurtu ratni dječji roman nabiera szczególnego znaczenia. Literatura ta bowiem - jak konstatuje Magdalena Dyras - „stawia sobie

${ }^{4} \mathrm{~W}$ przypadku chorwackich powieści wojennych dla dzieci kategoria przygodowości jest jedną z kluczowych. Między innymi w oparciu o nią chorwackie badaczki literatury dziecięcej, Dubravka Težak oraz Dubravka Zima, dokonały klasyfikacji utworów zaliczanych do analizowanego nurtu. Pierwsza z nich w jego ramach wyróżnia: powieści przygodowe, teksty starające się być dokumentami czasu oraz utwory o charakterze fantastycznym (cf. Težak, 1997, 42-43). Z Kolei Dubravka Zima wymienia dwie strategie narracyjne, które ujmują wojnę jako proces dojrzewania (rat kao sazrijevanje) oraz jako przygodę (rat kao pustolovina) (cf. Zima, 2001, 85).

${ }^{5}$ Powyższe cechy literatury dziecięcej wyróżnia m.in. Zofia Adamczykowa, nazywając je kategoriami immanentnymi (Adamczykowa, 2008, 29). 
za cel odpowiednie ukształtowanie dziecięcego światopoglądu”, a „w wypowiedziach małych bohaterów [...] dochodzi do głosu swoista propagandowość, gdzie sensy ideologiczne podsuwane są czytelnikom jako sprawozdania z rzeczywistości” (Dyras, 1999, 186, 189). Wizja konfliktu, którą chorwaccy twórcy skierowali do najmłodszych odbiorców, bazuje na stereotypach oraz uproszczeniach dzielących świat na dobrych (Chorwatów) i złych (Serbów) oraz zbieżna jest z obrazem wojny utrwalonym w publicystyce ${ }^{6}$.

W omawianym tu nurcie prozy dziecięcej wyróżnić można także grupę tekstów, których bohaterami, oprócz dzieci, są zwierzęta, głównie psy. Ciekawe ich portrety stworzyli Maja Gluščević w powieści Ivin Vučko oraz Josip Laća (Alfi se vraća kući, 2007) i Stijepa Mijović Kočan (Kučak s Prevlake, 2004). W przywołanych tu tekstach na plan pierwszy wysuwa się niezwykła przyjaźń łącząca dzieci i zwierzęta, która szczególnego znaczenia nabiera w trakcie wojennej zawieruchy. Pupile niejednokrotnie ratują swoich opiekunów z opresji, ryzykując przy tym życiem. Są nie tylko świadkami wojennego okrucieństwa, ale również doświadczają go na własnej skórze. Zwierzęta przedstawione są najczęściej w sposób realistyczny ${ }^{7}$, „onakve kakve jesu tj. kao potka za njihov prikaz služe znanstvene

${ }^{6}$ Magdalena Dyras, poddając analizie utwory Ubili su mi kuću Milana Kušca, Strah me, mama Nikoli Pulicia oraz Mali ratni dnevnik Stjepana Tomaša, zauważa, że bohaterowie wiedzę na temat wojny czerpali głównie z telewizji. Wpływ komentarza telewizyjnego ujawnia się w ich wypowiedziach, stanowiących często powtórzenie zasłyszanego tekstu (Dyras, 1999, 188-189). Negatywne stereotypy serbskich żołnierzy obecne są także w pozostałych powieściach zaliczanych do nurtu ratni dječji roman. Problem ten omawiam w artykule Sindrom višejezičnosti u hrvatskim dečijim romanima o Domovinskom ratu (Ślawska, 2020, 81-90).

${ }^{7}$ Odwołuję się do funkcjonującego w chorwackich opracowaniach poświęconych animalistyce dziecięcej podziału na dwa sposoby ukazywania zwierząt - realistycznego (realistički, zbiljski, naturalistički) oraz antropomorficznego (antropomorfni); (v. Hameršak, Zima, 2015, 312; Batinić, 2013, 88-89; Crnković, Težak, 2002, 29; Hranjec, 1998, 230). Niektórzy badacze w ramach tego dychotomicznego podziału wyróżniają również podtypy. Jako przykład może posłużyć typologia Milana Crnkovicia, który wymienia: „1. antropomorfno prikazivanje životinja gdje antropomorfnosti nije svrha da potcrtava zbiljske osobine životinja, nego ima druge ciljeve; 2. prikazivanje životinja s dodavanjem nekih ljudskih osobina (govor), ali te dodane osobine samo brže i jednostavnije informiraju o onome što životinja osjeća i čini; 3. realističko opisivanje životinja na temelju zapažanja i promatranja; 4. kombinacija umjetničkog i naučnog opisivanja životinjskog svijeta gdje su naučni podaci uklopljeni u doživljaj prirode" (Crnković, 1967, 179, cyt. za: Hamršak, Zima, 2015, 312). 
predodžbe animalnog svijeta" (Slunjski, 2020, 123; cf. Crnković, Težak, 2002, 29). Czytelnik zaś obserwuje nie tylko ich zachowanie w codziennych sytuacjach, ale również widzi, jak poprzez zmianę nawyków dostosowują się do nowych warunków. Na tym tle wyróżnia się powieść Crobinhoodovi autorstwa Dunji Kalilić. Jest to jeden z nielicznych utworów, w którym głównymi bohaterami nie są dzieci ani nawet ludzie ${ }^{8}$. Autorka przedstawia losy mieszkających w ostrzeliwanym Dubrowniku psów i kotów, które stają się świadkami tragedii miasta. Ich postawa nie ogranicza się jednak do bycia biernymi obserwatorami. Postanawiają podjąć walkę z agresorem oraz nieść pomoc słabszym - zostają Crobinhoodami, wzorującymi się na Robin Hoodzie obrońcami ojczyzny i rodaków.

Utwory ukazujące wojenne historie z perspektywy zwierząt cieszą się w ostatnim czasie sporym zainteresowaniem badaczy, których rozważania nad wojną i ludobójstwem łączą się ze studiami nad zwierzętami ${ }^{9}$. W niniejszym szkicu pragnę prześledzić, w jaki sposób postaci zwierzęce wykorzystane zostały w utworze dla dzieci ukazującym serbską agresję na Chorwację. Uwagę poświęcę zwłaszcza kwestii stereotypów, a moja analiza rozwijać się będzie w trzech kierunkach - stereotypów dotyczących zwierząt, stereotypowych ujęć zwierząt i ludzi oraz stereotypów etnicznych - wyznaczających jednocześnie kolejne części pracy.

\section{Jak pies z kotem..., czyli w kręgu archetypów i stereotypów}

Powieść Dunji Kalilić traktuje o autentycznych wydarzenia z grudnia 1991 roku, w których centrum znalazły się fikcyjne zwierzęta - dwa psy,

\footnotetext{
Nowsze badania z kolei akcentują, że postaci zwierzęce w utworach dla dzieci i młodzieży nie mogą być analizowane jedynie jako ich ujęcia realistyczne lub antropomorficzne, gdyż jak podkreślają Marijana Hameršak i Dubravka Zima - „dječjeknjiževne životinje nužno, makar u tragovima su antropomorfne" (Hameršak, Zima, 2015, 313).

${ }^{8}$ Innym utworem łamiącym zasadę rówieśnictwa głównych bohaterów i potencjalnych odbiorców tekstu jest powieść Nady Iveljić Čuvarice novih krovova, w której pojawiają się wiły.

${ }^{9}$ Taką perspektywę badawczą odnaleźć można w pracach następujących uczonych: Baratay (2014; 2017); Czapliński (2017); Dobrosielski, Sulej (2017); Jarzyna (2017); Krupiński (2016).
} 
Ćoro i Lujo, kotka Maja oraz jej przyjaciółka Čina wraz ze swoim nowonarodzonym potomstwem, a także dwa kocury - Mačak i Tigar. Wybór tych właśnie gatunków na bohaterów utworu nie pozostaje bez znaczenia, są to bowiem zwierzęta, ,których los - jak podkreśla Piotr Krupiński - bez wątpienia w największym stopniu był i jest spleciony z człowiekiem" (Krupiński, 2016, 279). Psy i koty to jedne z najpopularniejszych gatunków towarzyszących ${ }^{10}$, wobec których ,właściciel posiada moralny obowiązek opieki [...], która wyraża się poprzez zapewnienie im odpowiedniego pożywienia i właściwych warunków bytowania oraz utrzymanie dobrego stanu zdrowia" (Smykowski, 2017, 445). W analizowanym tu utworze zwierzęta, pierwotnie pozbawione przez człowieka wolności, żyją poza jego władzą i doskonale sobie bez niego radzą. Co ważne, nie zostały porzucone przez swoich właścicieli, ale z własnej woli pozostały bądź wróciły do miasta, do którego wielkimi krokami zbliżała się wojna, gdyż - jak mówi jeden z bohaterów: „Za mene ne postoji drugi dom!... A, čuj, kakav bih to ja bio pas sa dva doma, ha?!" (Kalilić, 1997, 15). Słowa Ćora potwierdzają utrwalone w świadomości zbiorowej wyobrażenia na temat psiej wierności, przywiązania czy wręcz ślepego oddania. Sięgają one czasów, gdy ludzie zdołali udomowić dzikie zwierzęta i przysposobić je do pilnowania domostw. Wzorzec wiernego psa-stróża znany jest w literaturze od dawna. Pierwszym stróżem był mitologiczny Cerber, stojący u wrót Hadesu. Nie jest to jednak obraz jedyny. Pies jest bowiem postrzegany jako „zwierzę symbolizujące spryt, egoizm, nawet okrucieństwo" (Niedziela, 2014, 32). Z tego też względu, jak podkreśla Bernadeta Niesporek-Szamburska: „Na archetyp zwierzęcia składają się dwa modele: pozytywny - wysoko wartościowy i negatywny" (Niesporek-Szamburska, 2006, 16), przy czym, jak dodaje badaczka: ,pobieżny przegląd dziecięcych i młodzieżowych lektur pozwala stwierdzić, że pies jako bohater utworów dla dzieci nawiązuje jedynie do swego pozytywnego modelu" (Niesporek-Szamburska, 2006, 16). Warto - jak sądzę - przyjrzeć się, czy Dunja Kalilić, kreując zwierzęce postaci, sięgnęła po archetypy i utrwalone w społeczeństwie stereotypy, a może z nimi walczy?

${ }^{10}$ „Zwierzęta towarzyszące to konie, psy, koty lub cała reszta innych istot chętnych do tego, by ulec biouspołecznieniu jako pies pomocnik, członek rodziny albo członek drużyny w międzygatunkowym sporcie" (Haraway, 2012, 251). 
Wizerunek psa w powieści Crobinhoodovi jest bezspornie pozytywny. Ćoro i Lujo ukazani zostali przede wszystkim jako wierni obrońcy i stróże domostwa. Gdy rodzina pierwszego z nich opuszczała Dubrownik, ten ukrył się w zaciszu swojej budy i mimo gorących próśb dzieci odmówił wyjazdu. „- Ne mogu izaći... [...] - Ja ne mogu otići! [...] A zašto bih ja odavde odlazio?!... Ovo je moj dom! Jedini!" (Kalilić, 1997, 12, 15) stwierdza. Z kolei Lujo, którego nowi właściciele wygnali z domu, niejednokrotnie wraca do rodzinnej Makošicy, by obserwować go z ukrycia. Przestawione w utworze psy strzegą nie tylko domostw, ale są również obrońcami zaprzyjaźnionych kotów, zwłaszcza kotek i ich potomstwa, co nawiązuje do utrwalonego w tradycji ludowej wizerunku psa jako obrońcy kobiet i dzieci (cf. Kopaliński, 1990, 318). Stając się Crobinhoodami, postanawiają natomiast strzec całej ojczyzny i jej mieszkańców. Tym samym Kalilić odwołała się do faktu, że psy od wieków wykorzystywane są w wojsku. Pisarka często podkreśla ich cechy - szybkość, odwagę, rozwinięty zmysł węchu i słuchu, zdolności tropienia, dobrą pamięć oraz doskonałą orientację przestrzenną - dzięki którym są doceniane jako zwierzęta wojenne.

Obraz kota utrwalony w powieści Crobinhoodovi nie jest tak jednoznacznie pozytywny jak - sięgając po stereotyp - jego odwiecznego wroga psa. Wśród kocich bohaterów możemy wyróżnić postaci żeńskie (Maja, Čina) oraz męskie (Mačak, Tigar). Kotkom przypisane zostały tradycyjne role kobiece - Čina jest matką, opiekuje się swoim potomstwem i dba o domowe zacisze, jest czuła i delikatna, Maja zaś, mimo że nie ma jeszcze potomstwa, także przejawia typowe cechy matki. Władysław Kopaliński zwraca uwagę, że kot uważany jest za symbol macierzyństwa, delikatności, a także wdzięku i czystości (Kopaliński, 1990, 164). Cechy te w powieści Kalilić uosabiają właśnie kotki. Kocury natomiast symbolizują drapieżność, chytrość, dumę, niezależność oraz nierzadko okrucieństwo. Zarówno Tigar, jak i Mačak aktywnie biorą udział w działaniach wojennych, przeprowadzają ataki na wroga, podczas których odnoszą rany. Różnice między światem „męskim” i ,kobiecym” ujawniają się też w opisach, w których autorka ukazuje zwierzęta w sposób niezwykle wnikliwy, żywy i plastyczny. Obrazy te są pełne barw i szczegółów oraz wzbogacają je elementy charakterystyki wewnętrznej. Kalilić zwraca uwagę nie tylko na cechy charakteru czy temperament, ale również na życie uczuciowe 
postaci. Szczegółowe opisy podkreślają urodę zwierząt oraz hiperbolizują ich indywidualność, co ilustrują fragmenty, w których Maja i Mačak pokazani są jako przeciwieństwa, dwie skrajności:

Uši su joj se ponosno uzdigle, a rep se valovito razmahao. Prošetala se izglađenim kamenim pločama, ravnomjerno pocupkujući kao da joj noga nije ni bila ranjena (Kalilić, 1997, 46).

Sunce je polako napuštalo nebo iznad Grada. Majina se bijela dlaka sve manje bijeljela, primajući novu, sivkastoplavu boju sumraka (Kalilić, 1997, 52).

[...] ona se lagano naginjala sad ulijevo, sad udesno, pa malo unatrag, pa još malo prema naprijed, izdužujući tako svoj vrat do nebotičnih dužina (Kalilić, 1997, 111).

Maja se pomakne i u valovitom poskoku zanese se u plesnu figuru. Tijelo joj se pretvori u bijelu leptiricu, koja je na trenutke lebdjela, a na trenutke se spuštala na zemlju, kao na mirisni cvijet (Kalilić, 1997, 115).

Veliki crn mačak, sav razbarušen. [...] Sve dlake na leđima stršile su mu poput bodlja, a glava mu je bila raščupana i puna dlaka divljakuša. Nekoliko dlačetina slijepilo se na vrhu glave u crne rogove (Kalilić, 1997, 24).

Kreštavo se nasmijao očima zlurado vrebajući njezin pogled. Zatim snažno šmrkne i pljune na pod. [...] - Još jedna mačka! Rekavši to, on kihne toliko snažno da se ona trgne. Protrljao je njušku, površno je obrisao i nakon toga bila mu je prljavija nego prije, a par tamnih dlaka ostalo mu je visjeti ispod njuške (Kalilić, 1997, 26, 27).

Iskesio je zube, posebno pokazujući svoje očnjake. Strašili su malo prema naprijed i tako izgledali još ubojitiji (Kalilić, 1997, 100).

Podczas lektury utworu uwagę czytelnika zwraca fakt, że Maja, niezależnie od okoliczności, w jakich zostaje ukazana, wnosi do opisu piękno, harmonię, swoistą doskonałość. Odnieść można wrażenie, że zwierzę staje się wręcz obiektem artystycznym, który jest obserwowany, podziwiany oraz komplementowany. Rozważania nad fenomenem kociej urody wzmacniają refleksje dotyczące charakteru i umysłowość bohaterki, które narrator wyprowadza z analizy jej relacji z pozostałymi zwierzętami. Kocur Mačak jest natomiast uosobieniem cech negatywnych zarówno tych dotyczących usposobienia, jak i zewnętrzności. „Onaj tko je crn iznutra i izvana, taj ni ne može vidjeti nijednu drugu boju osim crne" (Kalilić, 1997, 53). Opisy, zdradzające nastawienie wobec niego nie tylko narratora, ale i pozostałych postaci, pozwalają zaliczyć kocura do grona tzw. trash animals. Termin ten jednoznacznie określa jego miejsce w świecie ludzi oraz, jak w przypadku utworu Kalilić, zwierząt. „«Śmieciowość» [...] definiowana jest jako zbiór takich cech jak: inwazyjność, nadliczebność, bezwartościowość dla człowieka, a nawet odrażający wygląd" 
(Rąbkowska, 2016, 34). W opisach kocura Mačaka uwagę zwraca przede wszystkim brud często również smród, które przypisywane są zwierzętom bezużytecznym, a więc śmieciowym. Natomiast spośród cech opisujących jego charakter wymienić należy w pierwszej kolejności nieposłuszeństwo i poczucie wolności. Nie respektuje on bowiem zasad odpowiedniego zachowania obowiązujących na zamieszkiwanej przez zwierzęta przestrzeni. Jego ,śmieciowość” wyraża się w ,nieracjonalnym przekonaniu, że zwierzę może podporządkować się [...] kategoryzacjom określającym, co jest użyteczne, a co nie" (Rąbkowska, 2016, 34). Niezależność i bunt bohatera uwidaczniają się również w języku. Kot jest bezczelny, opryskliwy, nierzadko agresywny, ignoruje inne zwierzęta oraz prowokuje je, w efekcie czego dochodzi do wielu utarczek słownych.

- Ho-ho-hooo! - zacereka se mačak. - Vrrrlo pametna gospođica!!! Mmm... Nemam pametnijeg posla nego gledati nekakve glupače što se skiću po mojem kvartu!

Ona ne odgovori odmah. Strignula je ušima, obliznula se pa onda rekla: [...]

- Kad je to već toliko važan posao, hoćeš li mi molim te reći što će ti ta traka?

- Ho-ćeš-li-mi-mo-lim-te-re-ći-što-će-ti-ta-tra-ka?!... - ponovi on, izrugujući se njezinim riječima. - Hu-hu-hu! Gospođica je doputovala iz inozemstva?... [...] S Marsa, možda?! (Kalilić, 1997, 25).

Stygmatyzacja Mačaka, którą dostrzegamy w wypowiedziach pozostałych bohaterów, osiąga punkt kulminacyjny, gdy kocur oskarżony o działania na rzecz wroga określony zostaje mianem ,„četnik” oraz „ratni profiter”. Z czasem okazuje się jednak, że nie jest on wcale tak zły, jak myślano o nim wcześniej. Bohatersko walczy na linii frontu, pomaga słabszym, ale nie obnosi się ze swoim pozytywnym zachowaniem. Zmianę jego postawy ilustruje również metamorfoza wizualna. Kocur dokonuje symbolicznego obmycia w Adriatyku, oczyszcza się ze wszystkich przywar oraz brudu i smrodu typowych dla kategorii trash animals. Tym samym przestaje być czarny w sensie dosłownym i przenośnym.

Mačak se verao, jedva se pomičući, a namočena dlaka potezala ga je stalno prema dolje.

Napokon, uspentrao se na greben, okrenuo trbuh prema suncu i ispružio se na leđa.

- Oh! - usklikne Maja. - Pa, on, on uopće nije crn!

- Trbuh mu je gotovo bijel! - iznenađeno reče Čina.

- A dlaka mu je siva, a ne crna... - reče Maja. [...]

- Pa ti uopće nisi crn! - reče ona.

Mačak podvije obje šape pod glavu i reče:

- Ma, nemoj!?... Pa jasno da nisam crn! (Kalilić, 1997, 171). 
Oprócz symbolu czarnego kota Kalilić sięgnęła również po stereotypowe wyobrażenie dotyczące kociej i psiej przyjaźni, które znajdują odbicie przede wszystkim w języku (voljeti se kao pas i mačka, živjeti kao pas i mačka, slagati se kao pas i mačka). Pisarka pokazuje, że przyjaźń psów i kotów jest możliwa, chociaż - jak się zdaje - same nie są o tym przekonane, wierząc ślepo w wyświechtany frazes.

- Ostanite ovdje, s nama - reče ona sanjivim glasom.

Ćoro i Lujo je zabunjeno pogledaju, a ona ponovi:

- Ostanite ovdje, s nama!

- Ali, vi ste mačke, a mi smo psi! - reče Ćoro.

- Pa, što onda? - upita Maja.

- Ne možemo živjeti zajedno! - reče Ćoro.

- Mi smo prijatelji! Zašto ne možemo živjeti zajedno? - upita ona (Kalilić, 1997, 180).

Dzięki przyjaźni psy i koty mogły wspólnie stawić czoła losowi, który zgotował im człowiek. Złe warunki, brak pożywienia i nieustanny strach wywoływany przez wybuchające granaty sprawiały, że życie zwierząt w ogarniętym wojną Dubrowniku stało się prawdziwym koszmarem. By podkreślić ich dramat, Kalilić kilkukrotnie sięga po struktury językowe ukazujące negatywną stronę bycia psem i kotem. Są to najczęściej związki frazeologiczne (mučiti se kao pas, osjećati se kao pas na lancu, postupati kao sa psom, raditi kao pas, ubiti kao psa, umoran kao pas, umrijeti kao pas, vući se kao pretučen pas, živijeti kao pas, kretati se sporo kao prebijena mačka, pretući koga kao mačku, vući mačku za rep), które podkreślają, że zwierzęta i ich obraz w literaturze oraz języku są zawsze uzależnione od postaw ludzi, którzy często traktują je niegodziwie. Kalilić, zabierając dziecięcych czytelników w miejsce, gdzie w wyraźny sposób manifestuje się niszczycielska władza człowieka obejmująca swoim zasięgiem także przyrodę, uwrażliwia ich na los „małych braci”.

\section{Zwierzęta-niezwierzęta, ludzie-nieludzie..., czyli o stereotypach raz jeszcze}

Podczas lektury powieści Crobinhoodovi uwagę zwraca także zatarcie granic pomiędzy humanitas i animalitas. Zwierzęcy bohaterowie ulegają w utworze Kalilić antropomorfizacji, zabiegowi, który znany jest 
w literaturze już od czasów bajki ezopowej. Postaci wykreowane przez chorwacką pisarkę mimo typowo zwierzęcej budowy ciała i typowych dla siebie relacji z innymi istotami mogą porozumiewać się (używać mowy) oraz kierować się rozumem. W ślad za Janiną Abramowską można je określić mianem hybryd ${ }^{11}$, przy czym owa hybrydalność nie dotyczy budowy ciała, ale ich zdolności komunikacyjnych (Abramowska, 2010, 127-128). Zastosowana w utworze Kalilić antropomorfizacja zwierząt jest posunięta naprawdę daleko, dochodzi wręcz do swoistego odwrócenia ról. Koty i psy zakładają wspólne domostwo, międzygatunkową wspólnotę, i zajmują jeden z dubrownickich pustostanów, w którym postanawiają żyć niczym w ludzkiej komunie, gromadzą zapasy pokarmu i następnie równo rozdzielają je między siebie. Aby prześledzić konstruowanie wizerunku uczłowieczonych zwierząt, warto przyjrzeć się bliżej dwóm podstawowym składnikom ich kreacji - ludzkiemu zachowaniu oraz zwierzęcym ograniczeniom. Zauważyć można, że bohaterowie powieści niejednokrotnie świadomie rezygnują z cech przypisanych ich gatunkom na rzecz typowo ludzkich przyzwyczajeń - wykonują wiele czynności przy użyciu przednich kończyn, stoją na dwóch łapach/nogach, witają się niczym ludzie, podając sobie łapę czy wreszcie szpiegują, łącząc tym samym zwierzęce cechy z ludzkim doświadczeniem. Mačak i Tigar walczą niczym mężczyźni, boksują, potrafią nawet, zadając potężny cios łapą, zabić człowieka. Ich wyczyny przedstawione są w tonie heroicznym (Mačak zdołał zabić trzech wrogich żołnierzy), dzięki czemu podkreślone zostały cnoty bohaterskie, takie jak: odwaga, roztropność, męstwo oraz znajomość wojennego rzemiosła. Dla pozostałych zwierząt mieszkających w murach miasta domagają się natomiast godnego - można powiedzieć - „ludzkiego” traktowania.

Upodobnianie się zwierząt do ludzi jest w analizowanym tu utworze częstym źródłem komizmu. Ćoro, który od urodzenia nie widzi na jedno oko, zasłania je przepaską niczym korsarz, Mačak z kolei nosi torbę, do której pakuje prowiant zdobyty w czasie akcji w górach i w ten sposób przenosi go do miasta. Zwierzęta, które pozostały w Dubrowniku, podobnie jak ludzie korzystają z pomocy humanitarnej wydawanej w specjalnie

${ }^{11}$ Badaczka podkreśla, że mianem tym określić można „,wszystkie zwierzęce postacie mniej lub bardziej umownie obdarzone cechami ludzkimi” i nie można ich mylić z monstrami (Abramowska, 2010, 73). 
zorganizowanych punktach. Za najbardziej radykalną próbę upodobnienia do ludzi uznać należy natomiast moment, gdy postanawiają nadać sobie nazwisko Crobinhood.

W powieści Dunji Kalilić równolegle do antropomorfizacji zwierząt obecne jest zjawisko zoomorfizacji ludzi. Zabieg ten ujawnia się przede wszystkich w epitetach i porównaniach odnoszących się do żołnierzy atakujących miasto z otaczających je wzgórz. Znamienne jest to, że zwierzęcy bohaterowie, wypowiadając się o nich, używają wyłącznie określenia „četnici”. Wrogowie ukazani są niczym bestie, monstra, które ani z ludźmi, ani ze zwierzętami, ani z zabytkami nie obchodzą się w cywilizowany sposób. Niszczą wszystko, co napotkają na swojej drodze. „Vidiš... kako je to grozno! I što nam rade zločesti ljudi! Četnici!” (Kalilić, 1997, 12). Co warte podkreślenia, zoomorfizacja dotyczy nie tylko ich postępowania, ale też wyglądu. Serbowie przedstawieni są najczęściej jako brodaci mężczyźni, którzy nie dbają o higienę, przez co bardziej przypominają dzikie zwierzęta niż ludzi. Często są pod wpływem alkoholu potęgującego ich „zwierzęce” odruchy. „Gore se iza brda sve crni od pijanih četnika” (Kalilić, 1997, 66) - zauważa Ćoro. Ich nieludzkie cechy wyrażają się również w języku, który przepełniony jest wulgaryzmami i agresją. Żołnierze najczęściej warczą, wyją, wrzeszczą, a nie mówią (szerzej na temat negatywnego stereotypu serbskiego żołnierza w chorwackich powieściach wojennych dla dzieci v. Ślawska, 2020). Pozostali bohaterowie wypowiadają się o nich z pogardą i zarzucają im ,zezwierzęcenie”, gdyż utarło się łączyć okrucieństwo z kondycją zwierzęcą. Oskarżani są również o kradzieże. „Svaki četnik je lopov” (Kalilić, 1997, 93) - stwierdza jeden z bohaterów. Z kolei mieszkańcy Dubrownika, o których Kalilić wprawdzie nie pisze, ale uwiecznił ich na towarzyszących tekstowi ilustracjach dubrownicki malarz Lukša Peko, przypominają bardziej istoty człekokształtne niż ludzi. Upodleni przez wojnę przestają być sobą również w wymiarze fizycznym.

Warto podkreślić, że w przypadku serbskich żołnierzy nie znamy ani ich imion, ani nazwisk, ani nawet twarzy, które ukryte zostały pod obfitym zarostem przypominającym zwierzęce futro. Kalilić, odbierając w ten sposób wrogom człowieczeństwo, klasyfikuje ich jako trash animas. „Śmieciowość” jest bowiem - jak podkreśla Ewelina Rąbkowska - „odnoszona także do człowieka. W nawiązaniu do niej mówi się o ludziach biednych, bezdomnych, z marginesu społecznego, obcych (imigrantach) 
i brudnych - subiektywna kategoria «śmieciowości» jest wartościująca, wyraża strach i obrzydzenie wobec Innego" (Rąbkowska, 2016, 34). Celem ukazania serbskich żołnierzy jako zwierząt jest wywołanie w dziecięcym czytelniku przekonania, że nie są pełnoprawnym gatunkiem ludzkim, co zresztą potwierdzają słowa Ćora: „To je neka druga vrsta živih bića!!!” (Kalilić, 1997, 16).

\section{Ludzkie zwierzęta i zezwierzęceni ludzie..., czyli o stereotypach po raz trzeci}

Dunja Kalilić w swoim tekście wiele miejsca poświęca „ludzkim” i „nieludzkim” zachowaniom ludzkich i nieludzkich postaci, odwołując się przy tym do pojęcia ,zwierzęcość”. Zastosowane przez nią zabiegi antropomorfizacji i zoomorfizacji odkrywają w tym, co ludzkie, to, co zwierzęce i odwrotnie, przy czym określenie „zwierzęcy”, a więc „nieludzki” ma wymiar pejoratywny. Autorka odwołuje się tym samym do utrwalonego w świadomości społecznej przekonania, że zwierzęta są ,gorsze” od ludzi. Człowiek-zwierzę utożsamia złe pragnienia i działania, preferuje przemoc oraz okrucieństwo. W taki sposób pisarka ukazuje serbskich żołnierzy, którzy zachowują się ,,jak zwierzęta”, a nie ,jak ludzie” - niszczą, zabijają i nie wzbraniają się przed naruszeniem jakiejkolwiek granicy. Ich bestialstwo sprawia, że zostają wyłączeni z ludzkiej wspólnoty, a jednocześnie, dzięki chwytowi antropomorficznemu, zostają do niej włączone dubrownickie (chorwackie), „ludzkie” zwierzęta, które pisarka utożsamia ze swoimi rodakami. Operując opozycją ludzki-nieludzki w odniesieniu do chorwackich i serbskich żołnierzy, autorka nie wykracza poza krąg stereotypów obecnych $\mathrm{w}$ tekstach zaliczanych do nurtu ratni dječji roman. Stereotypowe ujęcia obcych/innych są jednym z nieodzownych elementów literatury, która jest - jak konstatuje Zofia Mitosek - „uprzywilejowaną dziedziną werbalnego wyrażania stereotypów" (Mitosek, 2001, 214). Badaczka podkreśla jednocześnie, że teksty pełnią wobec stereotypu trzy funkcje - utrwalającą, kreującą i obnażającą (deszyfrującą) (Mitosek, 2001, 214). W przypadku powieści Dunji Kalilić mamy do czynienia z pierwszą z nich. Utwór stabilizuje stereotyp złego i okrutnego serbskiego żołnierza oraz dzielnego, prawego, walecznego Chorwata, prowadząc dziecięcego 
odbiorcę do całkowitej aprobaty takiego obrazu świata. Konieczna jest do tego - jak słusznie zauważa Bernadeta Niesporek-Szamburska - „«dobra wiara» czytelnika, czyli przekonanie o autentyczności wizji, jaką oferuje tekst" (Niesporek-Szamburska, 2013, 22). Utrwalone w powieści wizerunki Serba i Chorwata potwierdzają niezbyt obszerną jeszcze wiedzę młodych ludzi, czerpaną z mediów, lektur szkolnych oraz podręczników, które - jak pokazują badania - często sięgają po stereotypy (v. Tomljenović, 2012).

\section{Zakończenie}

Reasumując rozważania na temat powieści Crobinhoodovi, podkreślić trzeba, że Dunja Kalilić daje się poznać jako wnikliwy obserwator kocich i psich zwyczajów oraz znawca czworonożnych osobowości. Ukazuje zwierzęta z ich wadami i zaletami, ujawnia słabostki i silne strony ich natury. Pisarka sięga po utrwalone w świadomości zbiorowej wyobrażenia na temat zwierząt (psia wierność, kocia niezależność) i przywołuje wiążące się z nimi symbole oraz stereotypy. Kreując zwierzęcych i niezwierzęcych bohaterów, wykorzystuje zabiegi antropomorfizacji i zoomorfizacji oraz kategorię trash animals, co doprowadza do zatarcia granicy pomiędzy tym, co ludzkie, i tym, co zwierzęce. Przyjęta przez nią strategia prowadzi do utrwalenia pozytywnych wyobrażeń na temat Chorwatów oraz negatywnego stereotypu serbskich żołnierzy, co owocuje - jak podkreśla Dubravka Zima - „snažnom ideologizacijom književnog svijeta, [...] iz čega slijedi i shematizirana interpretacija rata" (Zima, 2001, 113). Dubrownickie psy i koty, które ukazane zostały najmłodszym odbiorcom jako wzór do naśladowania, dają wyraz swojego bohaterstwa, odpowiedzialności i troskliwości. Badacze literatury dziecięcej zwracają uwagę, że postaci literackie, aby pełnić funkcje wzorów osobowych, muszą być wyraziste, gdyż tylko wtedy mogą pobudzać wyobraźnię i emocje czytelnika. Cech tych z pewnością nie brakuje Crobinhoodom. Są to postaci aktywne, podejmujące działania, mające pomóc dzieciom w odnalezieniu siebie i swojego miejsca w nowym porządku świata.

Literatura o czasach wojny zawsze jest lekcją, i jak każda lekcja może być porywająca, nudna, przeładowana lub niepełna (Heska-Kwaśniewicz, 2009, 10). Lekcja, na którą Dunja Kalilić zaprasza chorwackie dzieci, ma 
wychowywać oraz kształtować ich światopogląd. Teksty dla najmłodszych w największym stopniu od utworów dla dorosłych odróżnia stosunek nadawcy komunikatu do jego odbiorców. Pisarz ze względu na swój wiek ma władzę nad dzieckiem, które czyta, słucha i ogląda, przejmując od niego przekonania oraz sposób widzenia świata. Uproszczony i ulepiony ze stereotypów obraz wrogich żołnierzy „najłatwiej zapada w pamięć, stając się zarazem elementem nauki schematycznego myślenia i czarnobiałych uogólnień" (Dyras, 1999, 192). Przedstawione w utworze Dunji Kalilić postaci i zdarzenia pretendują do tego, by odczytywać je jako interpretacyjne modele świata pozaliterackiego.

\section{Literatura}

Abramowska, J. (2010). Pisarze w zwierzyńcu. Poznań: Wydawnictwo Poznańskie.

Adamczykowa, Z. (2008). Literatura ,czwarta” $-w$ kręgu zagadnień teoretycznych. W: Literatura dla dzieci i młodzieży (po r. 1980). Red. K. Heska-Kwaśniewicz. Katowice: Wydawnictwo Uniwersytetu Śląskiego, s. 13-43.

Baratay, É. (2014). Zwierzęcy punkt widzenia. Inna wersja historii. Przeł. P. Tarasewicz. Gdańsk: Wydawnictwo w Podwórku.

Baratay, É. (2017). Zwierzęta w okopach. Zapomniane historie. Przeł. B. Brzezicka. Gdańsk: Wydawnictwo w Podwórku.

Batinić, A. (2013). U carstvu životinja. Animalističko čitanje hrvatskih dječjih časopisa. Zagreb: Hrvatska sveučilišna naklada, Filozofski fakultet.

Batinić, Š., Majhut, B. (2001). Od slikovnjaka do Vragobe. Hrvatske slikovnice do 1945. Zagreb: Hrvatski školski muzej.

Cieślikowski, J. (1975). Literatura i popkultura dziecięca. Wrocław: Zakład Narodowy im. Ossolińskich.

Crnković, M. (1967). Dječja književnost. Priručnik za studente pedagoških akademija $i$ nastavnike. Zagreb: Školska knjiga.

Crnković, M., Težak, D. (2002). Povijest hrvatske dječje književnosti od početka do 1955. godine. Zagreb: Znanje.

Czapliński, P. (2017). Poszerzanie pola Zagłady. „Teksty Drugie” nr 2, s. 7-17. https:// doi.org/10.18318/td.2017.2.1.

Dobrosielski, P., Sulej, K. (2017). Zwierzę. W: Ślady Holokaustu w imaginarium kultury polskiej. Red. J. Kowalska-Leder, P. Dobrosielski, I. Kurz, M. Szpakowska. Warszawa: Wydawnictwo Krytyki Politycznej, s. 507-532.

Dyras, M. (1999). Chorwacka literatura dziecięca wobec sytuacji po 1991 roku. W: Przemiany w świadomości i kulturze duchowej narodów Jugosławii po 1991 roku. Red. J. Kornhauser. Kraków: Wydawnictwo Uniwersytetu Jagiellońskiego, s. 185-194. 
Hameršak, M., Zima, D. (2015). Uvod u dječju književnost. Zagreb: Leykam international.

Haraway, D. (2012). Manifest gatunków stowarzyszonych. Przeł. J. Bednarek. W: Teorie wywrotowe. Antologia przekladów. Red. A. Gajewska. Poznań: Wydawnictwo Poznańskie, s. 241-260.

Heska-Kwaśniewicz, K. (2009). O wojnie i okupacji w literaturze dla młodych odbiorców. Rekonesans. „Guliwer” nr 1, s. 5-10.

Hranjec, S. (1998). Hrvatski dječji roman. Zagreb: Znanje.

Jarzyna, A. (2017). Poza imaginarium. O miejscu zwierząt w narracjach o Zagładzie i Zagłady w narracjach o zwierzętach. „Narracje o Zagładzie” nr 3, s. 7-18.

Kalilić, D. (1997). Crobinhoodovi. Split: Marjan knjiga.

Kopaliński, W. (1990). Stownik symboli. Warszawa: Wiedza Powszechna.

Krupiński, P. (2016). „Dlaczego gęsi krzyczały?”. Zwierzęta i Zagłada w literaturze polskiej XX i XXI wieku. Warszawa: Instytut Badań Literackich PAN.

Kujundžić, N. (2015). Prijateljstvo djece i životinja. „Književnost i dijete” t. IV, br. $3-4$, s. 28-47.

Majhut, B. (2005). Pustolov, siroče i dječja družba: hrvatski dječji roman do 1945. Zagreb: FF press, Filozofski fakultet.

Mitosek, Z. (2001). Literatura i stereotypy. Próba typologii i opisu relacji. W: Stereotypy $i$ uprzedzenia. Uwarunkowania psychologiczne i kulturowe. Red. M. Kofta, A. Jasińska-Kania. Warszawa: Wydawnictwo Naukowe Scholar, s. 214-223.

Niedziela, S. (2014). Zwierzyniec literacki. Warszawa: Wydawnictwo Stowarzyszenia Bibliotekarzy Polskich.

Niesporek-Szamburska, B. (2006). W orszaku małego człowieka, czyli o psie w tekstach dla dzieci. „Guliwer” nr 3, s. 14-22.

Niesporek-Szamburska, B. (2013). Wokót stereotypu. W: B. Niesporek-Szamburska. Stereotyp czarownicy i jego modyfikowanie. Na przyktadzie tekstów dla dzieci $i$ wypowiedzi dziecięcych. Katowice: Wydawnictwo Uniwersytetu Śląskiego, s. $11-25$.

Pilaš, B. (1998). Domovinski rat u hrvatskoj prozi za djecu. U: Odrastanje u zrcalu suvremene književnosti za djecu i mladež. Prired. R. Javor. Zagreb: Knjižnice grada Zagreba, s. 32-39.

Rąbkowska, E. (2016). , Śmieciowe” zwierzęta (trash animals) $i$ „,dzieci śmieci”. Relacje dziecka i zwierzęcia w literaturze dla dzieci i młodzieży. W: Czytanie menażerii. Zwierzęta w literaturze dziecięcej, młodzieżowej i fantastycznej. Red. A. Mik, P. Pokora, M. Skowera. Warszawa: Wydawnictwo Stowarzyszenia Bibliotekarzy Polskich, s. 31-51.

Slunjski, K. (2020). Animalistički sloj u romanima Maje Gluščević (90. godine 20. stoljeća). „Detinjstvo” t. XLVI, br. 2, s. 121-132.

Smykowski, K. (2017). Człowiek i zwierzęta towarzyszace. Refleksje teologa moralisty. „Verbum Vitae” nr 32, s. 445-460.

Ślawska, M. (2020). Sindrom višejezičnosti u hrvatskim dečijim romanima o domovinskom ratu. „Detinjstvo” t. XLVI, br. 1, s. 81-90. 
Težak, D. (1997). Prozna djela dječje književnosti s tematikom rata. U: Dječja knjiga u Hrvatskoj danas. Teme i problemi. Prired. R. Javor. Zagreb: Knjižnice grada Zagreba, s. 42-50.

Tomljenović, A. (2012). Slika Hrvata u srpskim i Srba u hrvatskim udžbenicima povijesti za osnovnu školu. „Povijest u nastavi” br. 19 (1), s. 1-32.

Visković, N. (2009). Kulturna zoologija. Što je životinja čovjeku i što je čovjek životinji. Zagreb: Naklada Jesenski i Turk.

Wądolny-Tatar, K. (2017). Dziecko i wojna w perspektywie postpamięci. Narracje dla najmłodszych. „Litteraria Copernicana” nr 3 (23), s. 111-124. DOI: http://dx.doi. org/10.12775/LC.2017.053.

Zalar, I. (1991). Pregled hrvatske dječje poezije. Zagreb: Školska knjiga.

Zima, D. (2001). Hrvatska dječja književnost o ratu. „Polemos” br. 4, s. 81-122. 